\title{
Cuts threaten Science Council
}

\section{Ottawa}

A STRONG voice for science may soon be stilled as part of a government effort to trim $\$ 1,000$ million from its budget.

The Science Council of Canada, which since its creation in 1966 has produced hundreds of reports on the impact of science and technology on society, is one of 46 advisory bodies that are being eliminated, consolidated, or spun off into the private sector, the country's finance minister, Don Mazankowski, announced last week. The moves are expected to save \$22 million annually.

The science council, with a staff of 29 and an annual budget of $\$ 3.2$ million, was influential in the 1970 s in helping to create a national space agency to oversee the country's cooperative efforts with the United States on the space shuttle and space station. Another council report foresaw the need for a 'conserver society' that would rely on research rather than natural resources as the chief engine of development for the nation. Other major projects have examined the country's approach to science education, the need to attract more women into science and the impact on society of computer technology.

Reacting quickly to the news, the council's chairperson, Janet Halliwell, said last week that she and her colleagues want to keep the council alive with a combination of private and government money. "Ideally, I would like to see a free-standing institute with links to universities and industry but one that also serves provincial and federal governments," she said. "Unfortunately, we don't have much time six months if we're lucky."

In recent years, however, the council has slipped into a sort of bureaucratic limbo. In 1985 its budget and staff were cut almost in half. And its role as the premier advisory body for science policy has been challenged by the National Advisory Board for Science and Technology, created and chaired by the prime minister, Brian Mulroney.

The demise of the council is seen as a symbol of the federal government's neglect of science and technology. That neglect stands in sharp contrast to the government's repeated insistence on the importance of research and development.

When Mulroney became prime minister in 1986, for example, he promised to double government spending on science. But spending has actually declined over the past five years. Canada remains in the bottom tier of industrialized nations in the percentage of its gross national product devoted to science - half as much as its chief competitors, the US and Germany - and the figure has dropped from 1.4 per cent in 1985 to 1.3 per cent in 1985 .
Both the science council and the newer national advisory board have had rough sledding of late. The board's recent recommendation to double the budgets of the research granting councils was ignored. Last year both groups, along with the NSERC and the National Research Council, told the government not to fund a $\$ 500$ million particle physics experiment, known as KAON, to be built in British Columbia and carried out with the help of the United States. But Mulroney ignored their advice and announced - timed to help a friendly provincial government in a forthcoming election - that he would provide at least $\$ 236$ million for the project.

These government policies have led to a steady decline in the level of support for the average scientist, from 53 percent of what was requested in 1983 to a current level of 46 per cent. Peter Morand, president of NSERC, has pointed out that the KAON experiment will benefit chiefly some 200 physicists, while his council's $\$ 480$ million budget must satisfy the training and research needs of some 20,000 researchers.

Although the government may feel that it has quite enough science policy advice to choose from, Stuart Smith, a past chairman of the science council, believes that the public will be the biggest loser if the council disappears. No other body in Canada, he says, can make the public so aware of science policy issues.

David Spurgeon

\section{Report asks more for academic science}

\section{Cape Town}

SouTh Africa should spend more of its research dollar on competitive, universitybased research, according to a report written for the body that advises the government on science. In the face of a decline in government research spending, however, any shift in priorities would necessarily come at the expense of existing activities.

The report to the Science Advisory Council (SAC) provides, for the first time, an analysis by category of the recipients of government funding. It shows that inhouse laboratories, those institutions supported by the government's five statutory councils, receive more than five times the amount of money given out to academic scientists. The 44 per cent consumed by those in-house laboratories is a far greater percentage than is the case in other industrial countries, while the 8 percent spent on academic science is far smaller than the norm. The largest single allocation, however - some 48 per cent - goes to the category of general university funding, which includes money from the state to pay faculty salaries.

Predictably, the report has been wel- comed by the universities. Dave Woods, Deputy Vice-Chancellor (Research) at the University of Cape Town, agrees that academic research is more competitive, easier to target and more flexible than research performed in-house by the councils. But Brian Clark, president of the Council for Scientific and Industrial Research (CSIR), disagrees. "Competition for funds goes on within a research council," he says, "but at a different level".

The report to SAC was written last fall, but made public only recently. It was prepared by the Foundation for Research Development (FRD), the statutory council responsible for funding scientific research in higher education. Its conclusion is that the current structure of research support in the country "underemphasizes competitive and targeted research funding mechanisms."

According to Chris Garbers, the chairman of SAC, the report is too late to influence the council's recommendations on the allocation of the science vote for the current fiscal year. But he predicts that "it will have repercussions" next year. Already under review is the current system by which the government makes grants available to the statutory councils and universities but does not dictate how they are spent.

The report was released at the same time as a biennial survey of R\&D expenditures. The survey found a continuing drop in research and development spending, from 0.93 per cent of the country's gross national product in 1985-86 to 0.86 per cent in 1989-90. By comparison, the United States, Japan and Germany spend more than 2.5 per cent of their GNPs, and most European nations spend between 1 and 2 per cent.

One potential loser, if the foundation's report were to be followed, is the CSIR. It receives the largest slice of the science budget, but it does not fund university research. But Clark defends its role. "Ours is mission-oriented research," he says, "directed at problem-solving".

The report does not examine defence spending, which is believed to constitute as much as half of the country's overall research budget. While military spending is expected to decline in the years ahead, it's unlikely that any savings will be redirected into civilian research. Michael Cherry 